\title{
Hubungan antara Insulin-like Growth Factor-1 dengan Pertumbuhan dan Perkembangan Anak Sindrom Down
}

\author{
Arifiyah, Asri Purwanti \\ Bagian Ilmu Kesehatan Anak Fakultas Kedokteran Universitas Diponegoro/Rumah sakit Dr. Kariadi, Semarang
}

Latar belakang. Sindrom Down adalah kelainan kromosom yang paling umum disebabkan oleh kelainan pada kromosom 21. Tumbuh kembang anak sindrom Down dipengaruhi oleh faktor hormonal insulin-like growth factor-1 (IGF-1). IGF-1 memediasi efek hormon pertumbuhan $(\mathrm{GH})$ dan berperan penting dalam regulasi pertumbuhan somatik dan pengembangan organ termasuk perkembangan otak.

Tujuan. Membuktikan korelasi IGF 1- dengan tingkat pertumbuhan dan perkembangan pada anak sindrom Down.

Metode. Studi cross-sectional pada anak sindrom Down yang sesuai dengan kriteria inklusi di Rumah Sakit Kariadi Semarang. Tes IGF-1 dilakukan dalam waktu bersamaan. Penilaian pertumbuhan digunakan WHO antropometri Z-skor, perkembangan dinilai dengan Denver-II, digunakan kuesioner perkembangan (DQ) di empat sektor. Analisis tes korelasi Spearman digunakan. Rasio prevalensi yang dianalisis menggunakan tabel $2 \times 2$.

Hasil. Subjek penelitian adalah 41 anak sindrom Down berusia 6 bulan sampai 6 tahun, terdiri dari 24 (58,5\%) laki-laki, 17 (41,5\%) perempuan. korelasi positif ditemukan antara IGF-1 dan WAZ $(r=0,373 ; p=0,016)$, WHZ $(r=0,459 ; p=0,03)$, pertumbuhan memanjang $(r=0,670 ; p=0,000)$, motorik kasar $(r=0,408 ; p=0,08)$, motorik halus $(r=0,334 ; p=0,033)$. IGF-1 rendah, menyebabkan gangguan pertumbuhan memanjang 7,2 kali, malnutrisi 3,6 kali, berat badan rendah 1,92 kali, motorik kasar tertunda 1,161 kali, dan motorik halus tertunda 1,241 kali lebih besar dari normal IGF-1 tingkat.

Kesimpulan. Terdapat korelasi yang signifikan antara IGF-1 dengan pertumbuhan dan perkembangan pada anak Down sindrom. Semakin rendah IGF-1 maka semakin tinggi untuk menderita kelainan pertumbuhan, berat badan, status gizi, serta motorik kasar, dan motorik halus tertunda. Sari Pediatri 2017;18(5):350-6

Kata kunci: faktor-1 insuline-like growth (IGF-1), sindrom Down, pertumbuhan dan perkembangan

\section{The Correlation of Insulin-Like Growth Factor-1 Levels with Growth and Development in Down Syndrome Children}

Arifiyah, Asri Purwanti

Background. Down syndrome is the most common chromosomal disorder caused by abnormality on 21st chromosome. Growth and development of Down syndrome children are affected by hormonal factors including insulin-like growth factor-1(IGF-1). IGF1 mediates the effects of growth hormone $(\mathrm{GH})$ and plays an important role in somatic growth regulation and organ development including brain development.

Objective. To prove the correlation of IGF-1 levels with growth and development in Down syndrome children.

Methods. This is a cross-sectional study in Down syndrome children who match the inclusion criteria at Kariadi Hospital Semarang. The IGF-1 level test; and growth and development assessment was done in the same time. The growth assessment using WHO anthropometry Z-score. The development was assessed by Denver-II, using the development quotient (DQ) in four sectors. The correlationt test using Spearman. The correlation coefficient expressed by $r$, and $p$ value $<0.05$ is significant. Prevalens ratio analyzed using $2 \times 2$ table.

Results. Subjects were 41 Down syndrome children aged 6 month to 6 year, consist of 24 (58.5 \%) males, 17 (41.5\%) females. Positive correlations were found between IGF-1 and WAZ $(r=0.373 ; p=0.016)$, WHZ $(r=0.459 ; p=0.03)$, longitudinal growth ( $r=0.670$; $\mathrm{p}=0.000)$, gross motor $(\mathrm{r}=0.408 ; \mathrm{p}=0.08)$, fine motor $(\mathrm{r}=0.334 ; \mathrm{p}=0.033)$. Low IGF-1 level significantly causing longitudinal growth disorder 7.2 times, malnutrition 3.6 times, low body weight 1.92 times, gross motor delayed 1.161 times, and fine motor delayed 1.241 times bigger than normal IGF-1 levels.

Conclusion. There were a significant correlation between IGF-1 and growth and development in Down syndrome children. The lower IGF-1 level the higher chance of getting abnormality in longitudinal growth, body weight, nutrional status, as well as gross motor delayed and fine motor delayed. Sari Pediatri 2017;18(5):350-6

Keywords : insulin-like growth factor-1 (IGF-1), Down syndrome, growth, development

Alamat korespondensi: Dr. Arifiyah, Dr. Asri Purwanti, SpA(K). Bagian Ilmu Kesehatan Anak Fakultas Kedokteran Universitas Diponegoro / Rumah sakit Dr. Kariadi, Semarang. Email: arifiyah_dr@yahoo.com 
S indrom Down adalah kelainan kromosom yang paling banyak dijumpai sebagai akibat adanya kelainan pada kromosom 21 yang dapat berbentuk trisomi 21, translokasi, atau mosaicism. Sindrom Down memiliki manifestasi klinis berupa hipotonia, ciri fisik yang khas, retardasi mental dan keterlambatan perkembangan. ${ }^{1,2}$ Berdasarkan data tahun 2000-2006, insiden sindrom Down di Amerika sekitar 1:800 kelahiran bayi hidup, ${ }^{3}$ sedangkan di Indonesia diperkirakan 300.000 anak dengan sindrom Down lahir setiap tahun. ${ }^{4}$ Harapan hidup pada pasien sindrom Down lebih rendah dibandingkan populasi umum, meskipun mulai meningkat pada dekade terakhir. Pada tahun 1940-an usia rata-rata kematian adalah 12 tahun, ${ }^{5}$ pada tahun 1983 adalah 25 tahun, sedangkan pada beberapa tahun terakhir angka harapan hidup meningkat menjadi 60 tahun. $^{6}$

Sindrom Down memiliki berbagai masalah kesehatan pada organ maupun sistem organ, diantaranya, kelainan jantung, tulang, mata, telinga hidung tenggorok, gastrointestinal, hematologi, imunologi, periodontal, serta kelainan endokrin. Masalah kesehatan tersebut tentunya akan memengaruhi kualitas hidup anak sindrom Down, termasuk pertumbuhan dan perkembangan. ${ }^{7}$ Pertumbuhan dan perkembangan anak dipengaruhi oleh berbagai faktor, antara lain faktor genetik, lingkungan sejak masa prenatal, natal, postnatal, nutrisi mencakup makronutrien dan mikronutrien, stimulasi, serta hormonal. ${ }^{8}$ Hormon yang memengaruhi antara lain hormon pertumbuhan, termasuk insulin-like growth factor-1 (IGF-1). ${ }^{9}$

Insulin-like growth factor-I adalah hormon yang memperantarai efek hormon pertumbuhan (growth hormone/ GH) dan berperan penting dalam regulasi pertumbuhan somatik dan perkembangan organ. ${ }^{10}$ Kadar IGF-1 menggambarkan rata-rata kadar GH harian. Tidak seperti GH, kadar IGF-1 tidak berfluktuasi sepanjang hari. ${ }^{11,12}$ Hormon GH dan IGF-1 sering dihubungkan dengan kondisi gangguan pertumbuhan dan perkembangan karena keterlambatan pertumbuhan terjadi pada saat hormon tersebut berperan penting dalam pertumbuhan. ${ }^{13}$

Beberapa penelitian menunjukkan kadar IGF-1 yang rendah pada anak sindrom Down, ${ }^{14,15}$ tetapi ada pula yang menyatakan kadar IGF-1 masih dalam batas normal. ${ }^{16}$ Penelitian Hestnes dan Ragusa menunjukkan bahwa kadar IGF-1 memiliki korelasi positif dengan usia, periode pubertas, dan tinggi badan, namun tidak berhubungan dengan BMI. ${ }^{14,16,17}$ Selain perannya pada pertumbuhan, IGF-1 juga diketahui memiliki peran yang penting pada perkembangan otak, namun perannya terhadap perkembangan pada anak belum banyak diteliti. ${ }^{18,19}$

Penelitian ini bertujuan untuk membuktikan hubungan antara kadar IGF-1 terhadap pertumbuhan dan perkembangan anak dengan sindrom Down.

\section{Metode}

Penelitian cross-sectional yang dilakukan pada anak sindrom Down di Poliklinik Anak atau Bangsal Anak RSUP Dr. Kariadi Semarang. Waktu penelitian adalah bulan Januari sampai Juni 2016.

Kriteria inklusi antara lain anak berusia 6 bulan -6 tahun dengan diagnosis sindrom Down secara klinis maupun melalui pemeriksaan analisis kromosom, anak lahir cukup bulan, berat lahir $\geq 2500-4000$ gram, dan bersedia mengikuti penelitian. Kriteria eksklusi adalah anak sindrom Down yang memiliki kelainan bawaan yang berat, antara lain penyakit jantung bawaan dengan gagal jantung Ross IV, penyakit coeliac, hipotiroid berat, gangguan pendengaran berat yang tidak dikoreksi, gizi buruk yang tidak diberi pengobatan.

Subjek penelitian dipilih dengan metode consequtive sampling. Perkiraan besaran sampel dihitung berdasarkan rumus besar sampel dan dibutuhkan minimal 38 anak. Subyek penelitian dilakukan pemeriksaan kadar IGF-1 dengan sampel darah beku sebanyak $3 \mathrm{cc}$. Penilaian pertumbuhan dengan pemeriksaan antropometri pada subjek penelitian dan penilaian perkembangan dengan DDST-II (Denver developmental screening test). Uji hipotesis dilakukan dengan uji Spearman. Koefisien korelasi dinyatakan dengan $r$ dan kemaknaan jika $p<0,05$. Kekuatan korelasi secara statistik dinilai dan diinterpretasi sebagai berikut, $r 0,0-<0,2$ sangat lemah; $r$ 0,2 - $<0,4$ lemah; r 0,4 - <0,6 sedang; r 0,6 - <0,8 kuat; r 0,8 - <1,0 sangat kuat.

\section{Hasil}

Selama periode penelitian bulan Januari sampai dengan Juni 2016 di RSUP Dr. Kariadi Semarang, didapatkan 41 subyek penelitian. Pemilihan subyek mulai usia 6 
bulan berdasarkan pada peran hormon pertumbuhan pasca natal dalam mengatur pertumbuhan dimulai pada usia 6 bulan, dan dibatasi sampai usia 6 tahun atau usia prasekolah. Karakteristik subyek penelitian tertera pada Tabel 1.

Dari 41 subyek penelitian tersebut, jenis kelamin laki-laki lebih banyak yaitu 24 anak $(58,5$ $\%)$, perempuan 17 anak (41,5\%). Usia rata-rata $33,07 \pm 20,54$ bulan, dengan usia termuda 8 bulan dan tertua 6 tahun. Subyek penelitian yang memiliki penyakit jantung bawaan 22 anak $(53,7 \%)$ dengan jenis PJB asianotik (VSD, ASD, PDA) dan sianotik (ToF). Subyek penelitian yang menderita gangguan pendengaran 8 anak (19,5\%), antara lain SNHL dan CHL. Kelainan mata terdapat pada 11 anak (26,8\%), berupa miopia, hipermetropia, strabismus, dan nistagmus. Tidak ada seorang pun mempunyai kelainan gastrointestinal dan hati. Kadar tiroid pada semua subyek saat dilakukan penelitan berada dalam kadar yang normal, dalam hal ini pada pasien dengan hipotiroid kongenital telah diberikan hormon tiroid peroral (levotiroksin).

Kadar IGF-1 rata-rata 58,34 $\pm 37,2 \mathrm{ng} / \mathrm{ml}$, dengan nilai median 50,7 ng/ml. Apabila dikelompokkan sesuai jenis kelamin dan usia didapatkan 5 anak (12,2 $\%)$ termasuk rendah, 36 anak $(87,8 \%)$ termasuk

Tabel 1. Karakteristik subyek penelitian

\begin{tabular}{|c|c|c|c|}
\hline Karakteristik & $\mathrm{N}(\%)$ & Rerata \pm SB & Median (min-max) \\
\hline Umur (bulan) & & $33,07 \pm 20,54$ & $26(8-72)$ \\
\hline $\begin{array}{l}\text { Jenis kelamin } \\
\text { Laki-laki }\end{array}$ & $24(58,5)$ & & \\
\hline Penyakit jantung bawaan & $22(53,7)$ & & \\
\hline Kelainan pendengaran & $8(19,5)$ & & \\
\hline Kelainan mata & $11(26,8)$ & & \\
\hline Kadar IGF-1 (ng/mL) Rendah & $5(12,2)$ & $58,34 \pm 37,20$ & $50,7(3,87-140,19)$ \\
\hline WAZ (SD) & & $-1,85 \pm 1,25$ & $-1,75(-4,17-2,05)$ \\
\hline BB sangat kurang & $5(12,2)$ & & \\
\hline BB kurang & $14(34,1)$ & & \\
\hline BB normal & $21(51,2)$ & & \\
\hline BB lebih & $1(2,4)$ & & \\
\hline HAZ (SD) & & $-2,45 \pm 1,04$ & $-2,49(-4,61-1,72)$ \\
\hline Perawakan sangat pendek & $10(24,4)$ & & \\
\hline Perawakan pendek & $19(46,5)$ & & \\
\hline Perawakan normal & $12(29,3)$ & & \\
\hline WHZ (SD) & & $-0,68 \pm 1,40$ & $-0,46(-3,82-1,91)$ \\
\hline Buruk & $3(7,3)$ & & \\
\hline Kurang & $6(14,6)$ & & \\
\hline Baik & $32(78,0)$ & & \\
\hline $\mathrm{HC}(\mathrm{SB})$ & & $-3,05 \pm-0,98$ & $-3,0(-5,8--1,0)$ \\
\hline Mikrosefal & $38(92,7)$ & & \\
\hline Mesosefal & $3(7,3)$ & & \\
\hline \multicolumn{4}{|l|}{ Arah garis pertumbuhan } \\
\hline Tidak normal & $10(24,4)$ & & \\
\hline Motorik kasar (\%) & & $52,56 \pm 24,79$ & $44,44(2,5-100)$ \\
\hline Tidak normal & $36(87,8)$ & & \\
\hline Motorik halus (\%) & & $61,23 \pm 24,19$ & $62,50(11,11-100)$ \\
\hline Tidak normal & $34(82,9)$ & & \\
\hline Bahasa (\%) & & $53,98 \pm 26,02$ & $56,25(0,0-100)$ \\
\hline Tidak normal & $37(90,2)$ & & \\
\hline Personal sosial (\%) & & $60,84 \pm 23,89$ & $63,93(5,0-100)$ \\
\hline Tidak normal & $36(87,8)$ & & \\
\hline
\end{tabular}


Arifyah dkk: Hubungan antara $I G F-1$ dengan pertumbuhan dan perkembangan anak sindrom Down

Tabel 2. Korelasi antara IGF-1 dengan parameter pertumbuhan anak sindrom Down

\begin{tabular}{lcc}
\hline Variabel & Koefisien korelasi $(\mathrm{r})$ & $\mathrm{p}$ \\
\hline IGF-1 dengan WAZ & 0,373 & $0,016^{*}$ \\
IGF-1 dengan HAZ & 0,111 & 0,491 \\
IGF-1 dengan WHZ & 0,459 & $0,003^{*}$ \\
IGF-1 dengan HC/Age & 0,096 & 0,552 \\
IGF-1 dengan Arah garis pertumbuhan & 0,670 & $0,001^{*}$ \\
\hline
\end{tabular}

*korelasi bermakna $(\mathrm{p}<0,05)$

Tabel 3. Korelasi IGF-1 dengan parameter perkembangan anak sindrom Down

\begin{tabular}{lcc}
\hline Variabel & Koefisien korelasi $(\mathrm{r})$ & $\mathrm{p}$ \\
\hline IGF-1 dengan motorik kasar & 0,408 & $0,008^{*}$ \\
IGF-1 dengan motorik halus & 0,334 & $0,033^{*}$ \\
IGF-1 dengan bahasa & 0,084 & 0,602 \\
IGF-1 dengan personal sosial & 0,218 & 0,171 \\
\hline
\end{tabular}

${ }^{*}$ korelasi bermakna $(\mathrm{p}<0,05)$

Tabel 4. Rasio prevalens pada variabel yang memiliki korelasi signifikan

\begin{tabular}{lcc}
\hline & Nilai RP & Interval kepercayaan \\
\hline IGF-1 dengan arah garis pertumbuhan & 7,200 & $3,192-16,240$ \\
IGF-1 dengan WHZ & 3,600 & $1,295-10,010$ \\
IGF-1 dengan WAZ & 1,920 & $1,070-3,444$ \\
IGF-1 dengan motorik kasar & 1,161 & $1,019-1,324$ \\
IGF-1 dengan motorik halus & 1,241 & $1,057-1,457$ \\
\hline
\end{tabular}

normal, dan tidak ada yang memiliki kadar IGF-1 tinggi.

Tabel 2 menunjukkan bahwa kadar IGF-1 memiliki korelasi kuat dan signifikan dengan arah garis pertumbuhan, arah korelasi positif $(\mathrm{r}=0,670$; $\mathrm{p}=0,001)$. Kadar IGF-1 juga memiliki korelasi sedang dan signifikan dengan WHZ, arah korelasi positif $(\mathrm{r}=0,459 ; \mathrm{p}=0,003)$. Sementara kadar IGF-1 dengan WAZ memiliki korelasi lemah dan signifikan, arah korelasi positif $(r=0,373 ; p=0,016)$. Dengan demikian, dapat dikatakan makin tinggi kadar IGF-1 semakin baik nilai berat badan berdasar umur anak, status gizi anak, dan arah pertumbuhannya.

Variabel yang menggambarkan parameter perkembangan meliputi motorik kasar, motorik halus, bahasa, dan personal sosial berdasarkan Denver-II dengan penilaian menggunakan development quuotient (DQ)menunjukkan bahwa IGF-1 memiliki korelasi sedang dan signifikan dengan kemampuan motorik kasar, arah korelasi positif $(r=0,408 ; \mathrm{p}=0,08)$; dan
IGF-1 memiliki korelasi lemah dan signifikan dengan kemampuan motorik halus, arah korelasi positif $(\mathrm{r}=$ 0,334; $\mathrm{p}=0,033)$. Namun, tidak didapatkan korelasi antara IGF-1 dengan kemampuan bahasa dan personal sosial. Dengan demikian dapat dikatakan bahwa semakin tinggi nilai IGF-1 semakin tinggi nilai DQ pada sektor motorik kasar dan motorik halus.

Variabel pertumbuhan dan perkembangan yang memiliki hubungan dengan IGF-1 dilakukan analisis untuk mengetahui nilai rasio prevalens. Untuk perkembangan ditentukan bahwa perkembangan normal apabila nilai $\mathrm{DQ} \geq 85 \%$. Tabel 4 menunjukkan bahwa anak dengan kadar IGF-1 rendah secara signifikan berisiko memiliki arah garis pertumbuhan yang tidak normal 7,2 kali lebih besar dibandingkan anak dengan kadar IGF-1 normal. Anak dengan kadar IGF-1 rendah secara signifikan berisiko memiliki nilai WHZ (status gizi) gizi kurang atau gizi buruk 3,6 kali lebih besar dibandingkan anak dengan kadar IGF-1 normal. 


\section{Pembahasan}

Didapatkan status gizi baik pada 32 (78,0\%) anak. Penilaian tinggi badan berdasarkan usia didapatkan sebagian besar memiliki perawakan pendek 19 (46,5 $\%)$ dan sangat pendek $10(24,4 \%)$ anak, sedangkan penilaian lingkar kepala hampir semua mikrosefal. Arah garis pertumbuhan normal pada 31 (75,6 \%) anak. Hal ini sejalan dengan penelitian yang dilakukan pada tahun 2012 oleh Kawanto dkk ${ }^{4}$ di RSCM Jakarta pada 60 anak dengan sindrom Down. Pada penelitian tersebut didapatkan status gizi baik $60 \%$, perawakan pendek $90 \%$, dan mikrosefal $75 \%$ anak yang diteliti. ${ }^{20}$

Penilaian perkembangan rerata DQ motorik kasar $(52,56 \pm 24,79) \%$; rerata DQ motorik halus $(61,23 \pm 24,19) \%$; rerata bahasa $(53,98 \pm 26,02) \%$; dan rerata DQ personal sosial $(60,84 \pm 23,89) \%$. Hasil tersebut tidak berbeda jauh dengan penelitian sebelumnya tahun 2008 oleh Wasant $\mathrm{dkk}^{21}$ yang menilai perkembangan anak dengan sindrom Down usia 3 sampai 6 tahun, dengan hasil DQ $(63,78 \pm 11,25) \%$. Namun, pada penelitian tersebut menggunakan penilaian perkembangan dengan capute scales cognitive adaptive test/ clinical linguistic \& auditory milestones scale (CAT/CLAMS) sehingga didapatkan DQ secara total, berbeda dengan Denver yang dapat dinilai pada 4 aspek perkembangan. Pada penelitian tersebut dikatakan bahwa sindrom Down merupakan penyebab genetik terbanyak dari retardasi mental.

Kadar IGF-1 rata-rata pada anak dengan sindrom Down usia 6 bulan -6 tahun adalah $(58,34 \pm 37,2)$ SD $\mathrm{ng} / \mathrm{ml}$, dengan nilai median $50,7 \mathrm{ng} / \mathrm{ml}$. Apabila dikelompokkan sesuai jenis kelamin dan usia didapatkan $36(87,8 \%)$ termasuk normal, 5 (12,2\%) termasuk rendah, dan tidak ada anak yang memiliki kadar IGF-1 yang tinggi. Hasil penelitian tersebut sejalan dengan penelitian terdahulu Ragusa $\mathrm{dkk}^{14}$ yang meneliti kadar IGF-1 pada sindrom Down, tetapi pada usia prepubertal dan pubertal. Penelitian tersebut memaparkan bahwa kadar IGF-1 pada sindrom Down $85 \%$ masih dalam batas normal sesuai usia.

Dari semua parameter pertumbuhan, setelah dilakukan analisis data didapatkan bahwa kadar IGF1 memiliki korelasi kuat dan bermakna dengan arah garis pertumbuhan, korelasi sedang dan bermakna dengan WHZ, korelasi lemah dan bermakna dengan WAZ, arah korelasi positif. Dengan demikian, dapat dikatakan semakin tinggi kadar IGF-1, semakin baik nilai berat badan berdasarkan umur anak, status gizi anak, dan arah pertumbuhan. Analisis rasio prevalens antara IGF-1 dengan arah garis pertumbuhan, WHZ, dan WAZ menunjukkan bahwa anak dengan kadar IGF-1 rendah berisiko memiliki arah garis pertumbuhan yang tidak normal 7,2 kali lebih besar dibandingkan anak dengan kadar IGF-1 normal. Anak dengan kadar IGF-1 rendah berisiko memiliki nilai WHZ (status gizi) gizi kurang atau gizi buruk 3,6 kali lebih besar dibandingkan anak dengan kadar IGF-1 normal. Anak dengan kadar IGF-1 rendah berisiko memiliki nilai WAZ (BB/U) berat badan kurang atau sangat kurang 1,92 kali lebih besar dibandingkan anak dengan kadar IGF-1 normal.

Penelitian terdahulu memaparkan bahwa IGF1 memengaruhi pertumbuhan linear intrauterin. Defisiensi hormon ini berpengaruh mulai dari awal kelahiran sampai masa anak, menyebabkan maturasi skeletal, dan pertumbuhan organ terhambat. Abnormalitas pertumbuhan ini menyebabkan volume otak yang kecil (terlihat dari lingkar kepala), ukuran jantung yang kecil (cardiomicria), dan acromicria (dagu yang kecil, tulang wajah yang tidak berkembang, tangan, dan kaki kecil). Defisiensi IGF1 juga menyebabkan hambatan perkembangan dan kelemahan sistem muskular. ${ }^{22}$ Pada penelitian ini menunjukkan korelasi IGF-1 terhadap berat badan anak, status nutrisi, dan arah garis pertumbuhan, tetapi tidak memiliki korelasi dengan panjang/tinggi badan.

Faktor yang memengaruhi pertumbuhan adalah faktor internal atau herediter, antara lain, jenis kelamin, ras, suku bangsa, serta faktor lingkungan yang meliputi lingkungan pranatal, postnatal, dan faktor hormonal. Faktor hormonal yang berperan dalam tumbuh kembang anak, somatotrofin (growth hormon) berperan dalam memengaruhi pertumbuhan tinggi badan, dengan menstimulasi terjadinya poliferasi sel kartigo dan sistem skeletal. Selain itu, hormon tiroid berfungsi menstimulasi metabolisme tubuh, glukokortikoid menstimulasi pertumbuhan sel interstisial dari testis untuk memproduksi testosteron dan ovarium untuk memproduksi esterogen untuk menstimulasi perkembangan seks. ${ }^{4,8,10}$

Literatur dan penelitian terdahulu mendapatkan bukti bahwa secara umum IGF-1 memiliki peran dalam pertumbuhan sebagai mediator endokrin hormon pertumbuhan yang memengaruhi aksi metabolik dan anabolik, sebagai parakrin dan autokrin yang mengatur pertumbuhan, diferensiasi, apoptosis dan transformasi sel. Insulin-like growth factor berperan dalam stimulasi 
proses anabolik, seperti sintesis DNA dan RNA, penyerapan asam amino dan glukosa, sintesis protein dan karbohidrat serta glikogen, juga berperan dalam proses diferensiasi dan proliferasi berbagai jenis sel. Peran IGF-1 pada proliferasi dan diferensiasi sel dalam tubuh, termasuk pertumbuhan tulang. ${ }^{23}$ Tidak terdapat korelasi bermakna antara IGF-1 dengan panjang/ tinggi badan anak sesuai usia (HAZ) karena subyek penelitian ini adalah anak sindrom Down yang secara genetik memiliki kecenderungan perawakan pendek. ${ }^{20}$ Kadar hormon tiroid saat pemeriksaan berada pada kisaran nilai normal, pada pasien sindrom Down yang menderita hipotiroid kongenital telah diberikan pengobatan levotiroksin.

Penelitian terdahulu pada hewan menunjukkan bahwa reseptor IGF-1 tersebar luas di otak, mampu meningkatkan mielinisasi dan jumlah neuron dan sinapsis, serta melindungi neuron dari apoptosis. Di samping itu, IGF-1 juga mengatur pertumbuhan selsel otak baru termasuk neuron ganglia, mengurangi apoptosis, meningkatkan sinaptogenesis selama perkembangan awal setelah kelahiran. ${ }^{18,19}$ Hormon IGF-1 diproduksi oleh semua tipe sel di sistem saraf pusat di korteks, hipokampus, serebelum, hipotalamus; dan juga memiliki peran dalam neuroplastisitas pada sistem saraf pusat. ${ }^{24}$

Hormon IGF-1 terbukti memiliki hubungan dengan perkembangan motorik kasar dan motorik halus. Kemampuan motorik ini merupakan hasil interaksi dari banyak faktor, yaitu perkembangan sistem saraf, kemampuan fisik yang memungkinkan untuk bergerak, dan lingkungan yang mendukung. Sistem saraf motorik ini bekerja melalui traktus piramidal atau traktus kortikalis yang berpusat pada korteks serebri sampai pada persarafan otot. Kadar IGF-1 memiliki peran pada proses mielinisasi, dapat meningkatkan jumlah neuron dan sinapsis, serta melindungi neuron dari apoptosis sehingga memiliki hubungan yang positif dengan sistem saraf motorik. 18,19

Kadar IGF-1 tidak memiliki hubungan dengan perkembangan bahasa dan personal sosial. Fungsi bahasa merupakan proses yang paling kompleks di antara fase perkembangan. Perkembangan bahasa pada anak dipengaruhi oleh berbagai faktor, mulai dari pusat pengendali bahasa yang terletak pada area Broca dan area Wernick di otak, fungsi pendengaran, dan faktor stimulasi. ${ }^{8}$ Didapatkan pasien sindrom Down dengan gangguan pendengaran $19,5 \%$, berupa sensorineural hearing loss (SNHL) dan conductive hearing loss (CHL). Personal sosial atau kemandirian pada anak juga dipengaruhi banyak faktor termasuk pola asuh dan faktor lingkungan. ${ }^{8}$ Pada penelitian ini faktor stimulasi, pola asuh, dan lingkungan tidak dilakukan penilaian.

\section{Kesimpulan dan Saran}

Terdapat hubungan antara kadar IGF-1 dengan WAZ, WHZ, arah garis pertumbuhan, perkembangan motorik kasar, dan motorik halus pada anak sindrom Down. Disarankan melakukan penelitian tentang hubungan kadar IGF-1 dengan pertumbuhan dan perkembangan anak sindrom Down, menggunakan parameter penilaian pertumbuhan dengan grafik pertumbuhan khusus sindrom Down; serta penilaian parameter perkembangan yang berbeda seperti capute scales cognitive adaptive test/ clinical linguistic \& auditory milestones scale (CAT/CLAMS), early language milestone scale (ELMS), atau Bayley mental scale of infant development (BSID). Dapat pula dilakukan penelitian kohort kadar IGF-1 sebagai faktor risiko, dilakukan pemantauan secara prospektif untuk melihat dampak terhadap pertumbuhan dan perkembangan pada anak sindrom Down.

\section{Daftar pustaka}

1. Roper RJ, Reeves RH. Understanding the basis for Down sydrome phenotypes. Plos Genet 2006;2:231-6.

2. Kaur A, Kaur A. Cytogenetic findings and risk factors for Down syndrome in Punjab. Int J Hum Genet 2013;13:113-8.

3. Parker S, Mai C, Canfield M. Update national birth prevalence estimates for selected birth defects in the United States 20042006. Birth Defects Res A Clin Mol Teratol 2010;88:1008-16.

4. Kawanto FH, Soedjatmiko. Pemantauan tumbuh kembang anak dengan sindrom Down. Sari Pediatri 2007;9:185-90.

5. Bittles A, Bower C, Glasson E. The four age of Down syndrome. Eur J Public Health 2007;17:221-5.

6. Henderson A, Lynch S, Wilkinson S, Hunter M. Adults with Down's syndrome: the prevalence of complications and health care in the community Br J Gen Pract 2007;57:50-5.

7. Marder E, Dennis J. Medical management of children with Down's syndrome. Curr Pediatr 2001;11:57-63.

8. Tanuwidjaya S. Konsep umum tumbuh kembang anak. Dalam: Narendra MB, Sularyo TS, Soetjiningsih, Suyitno $H$, Ranuh IG, penyunting. Buku Ajar Tumbuh Kembang Anak 
dan Remaja. Edisi ke-2. Jakarta: Sagung Seto; 2005.

9. Batubara J, Triadjaja B, Pulungan A. Pertumbuhan dan gangguan pertumbuhan. Di dalam: Buku Ajar Endokrinologi Anak. Jakarta: Badan Penerbit IDAI; 2010.h.19-28.

10. Laron Z. Insulin-like growth factor (IGF-1): a growth hormone. J Clin Pathol 2001;54:311-6.

11. Clemons D. Clinical utility of measurements of insulin-like growth factor 1. Nat Clin Pract Endocrinol Metab 2006;2:43646.

12. Skottner A. Biosynthesis of growth hormone and insulin-like growth factor-I and the regulation of their secretion. Open Endocrinol J 2012;6:3-12.

13. Myrelid A. Current knowledge on growth hormone and insulin-like growth factors and their role in the central nervous system: growth hormone in down syndrome. Open Endocrinol J 2012;6:103-9.

14. Ragusa L, Valetto MR, Proto C, Alberti A, Romano C, Rossodivita A, dkk. IGF-1 levels in prepubertal and pubertal children with Down syndrome. Minerva Endocrinol 1998;23:31-6.

15. Cowans NJ, Stamatopoulou A, Spencer K. First trimester maternal serum placental growth factor in trisomy 21 pregnancies. Prenat Diagn. 2010;30:449-53.

16. Hestnes A, Stovner LJ, Husoy O, Folling I, Sjaastad O. Somatomedin C (insulin-like growth factor 1) in adults with
Down's syndrome. J Ment Defiency Research 1991;35:204-8.

17. Ragusa L, Protob C, Alberti A, Romano C, Rossodivita A, Colabucci F. IGF-1 levels in Down syndrome. Downs Syndr Res Pract 1998;5:123-5.

18. Ohlsson C, Mohan S, Sjögren K, Tivesten A, Isgaard J, Isaksson $\mathrm{O}$, dkk. The role of liver-derived insulin-like growth factor-I. Endocr Rev 2009;30:494-535.

19. D'Ercole J, PY. Expanding the mind: insulin-like growth factor I and brain development. Endocrinol 2008;149:5958-62.

20. Kawanto FH, Soedjatmiko, Hendarto A. Factors associated with intelligence in young children with Down syndrome. Paediatric Indones 2012;52:194-9.

21. Wasant P, Boonyawat B, Tritilanunt S, Vatanavicharn N, Sathienkijakanchai A, Ratanarak P, dkk. Factors influencing development of Down syndrome children in the first three years of life: Siriraj experience. J Med Assoc Thai 2008;91:1030-7.

22. Puche JE, Cortazar IC. Human conditions of insulin-like growth factor-I (IGF-I) deficiency. J Transl Med 2012;10:1-29.

23. Lelbach A, Muzes G, Feher J. The insulin-like growth factor system: IGFs, IGF-binding proteins and IGFBP-proteases. Acta Pharm Hung 2005;92:97-107.

24. Dyer A, Vahdaptour C, Sanfeliu A, Tropea D. The role of insulinlike growth factor-1 (IGF-1) in brain development, maturation, and neuroplasticity. Neuroscience. 2016;325:89-99. 